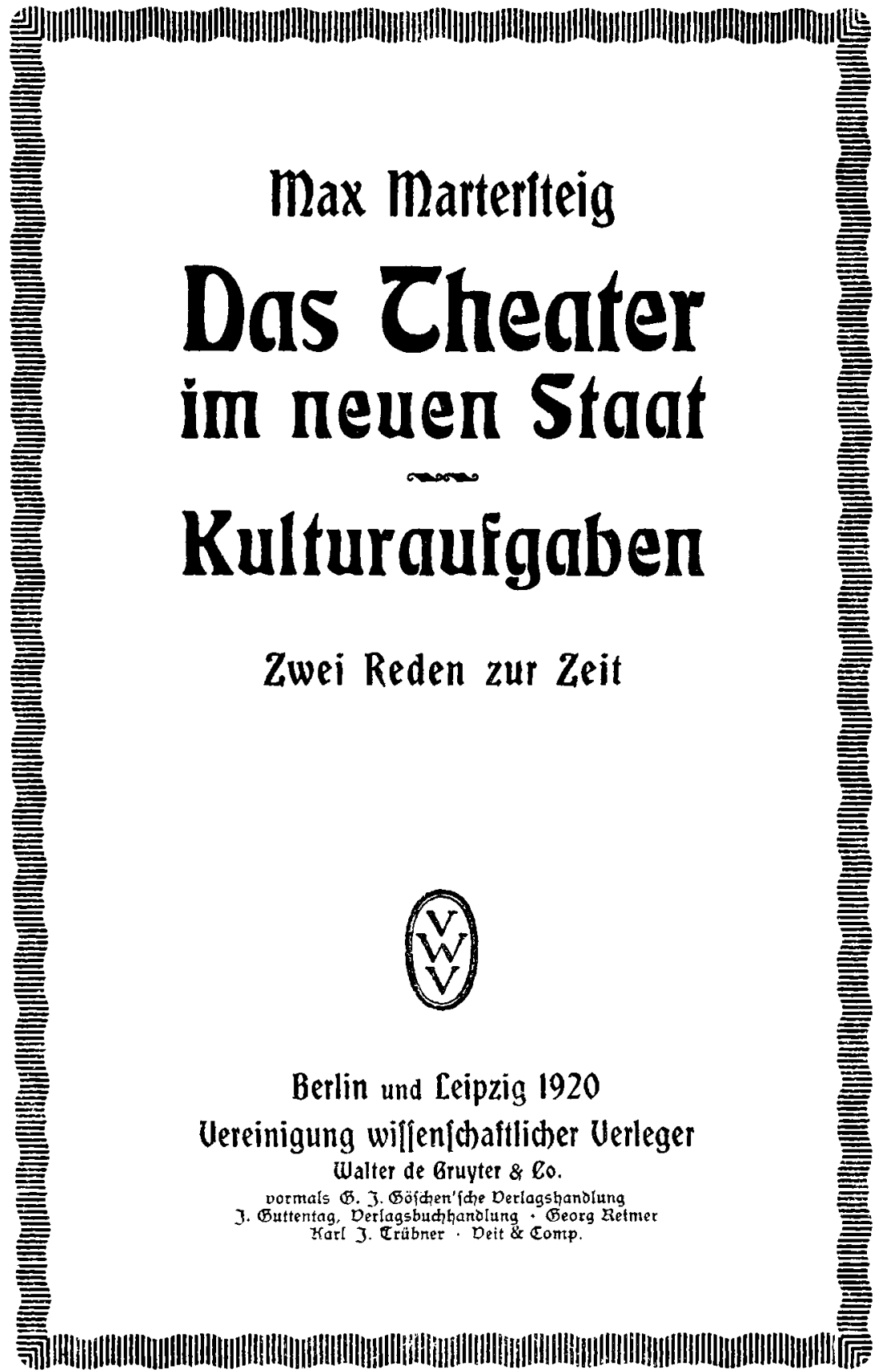





\title{
Max Marteriteig
}

\section{Das Cheater im neuen Staat}

\subsection{0 \\ Rulturaufgaben}

\author{
3 wei Reden $3 \mathfrak{u r}$ 3eit
}

In otto:

Dolterleben hat feine natürliden Brensen, mie meniderlebert fie hat. uno lediglid, oura getîtige 2 äabte tönnen Dölter jung erhalten uno wieder Derjüngt werben. Eagarbe.

\section{Berlin und Eeipzig 1920}

Dereinigung wilfenfdaftlider berleger walter de Grunter \& $\mathbb{C}$.

Dormals B. T. Böjфen'fhe Derlagsbanolung :: 3. Battentag, Derlags: buchardung :: Beorg Reimer :: Karl J. Trabner :: Deit \& Comp. 


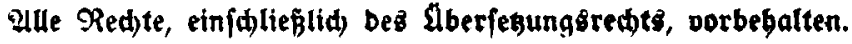

Drud oon Mesger a mittig tn fetpjig. 